\title{
The Effectiveness of Methylphenidate in the Treatment of Encopresis Independent from Attention-Deficit Hyperactivity Disorder Symptoms
}

\author{
Ömer Faruk Akça ${ }^{凶}$ and Savaş Yılmaz \\ Department of Child and Adolescent Psychiatry, Necmettin Erbakan University, Meram School of Medicine, Konya, Turkey
}

Several medications are reported to be effective in treatment of encopresis. However, mechanisms of action related to these drugs are not known. We report a patient with ADHD and encopresis whose encopretic signs have disappeared with long acting methylphenidate while they have not changed with atomoxetine.

Psychiatry Investig 2015;12(1):150-151

Key Words Methylphenidate, Atomoxetine, Encopresis, Attention-deficit hyperactivity disorder.

\section{INTRODUCTION}

Attention-deficit hyperactivity disorder (ADHD) is among the most frequently reported coexisting psychiatric condition in children with encopresis. ${ }^{1}$ Some case reports and a retrospective study state that methylphenidate (MPH) is effective in the treatment of encopresis that accompanies ADHD. ${ }^{2-5}$ However, the mechanism of action related to this medication in the treatment of encopresis is not well-known.

\section{CASE}

An eight-year-old boy was referred to our clinic with complaints of encopresis and constipation which occurs during last 2.5 years. The patient had also experienced over activity, behavior, and concentration problems since he was three years old. He was assessed by a pediatrician before admission to our clinic, and neither pathological findings nor gastroenterological disease, which could have explained the encopretic symptoms were found except the constipation during his

Received: September 2, 2013 Revised: October 22, 2013

Accepted: October 22, 2013 Available online: January 12, 2015

$\triangle$ Correspondence: Ömer Faruk Akça, MD

Department of Child and Adolescent Psychiatry, Necmettin Erbakan University, Meram School of Medicine, Meram, Konya, Turkey

Tel: +90-332-223-6859, Fax: +90-362-431-7855

E-mail: dromerakca@gmail.com

(a) This is an Open Access article distributed under the terms of the Creative Commons Attribution Non-Commercial License (http://creativecommons.org/licenses/bync/3.0) which permits unrestricted non-commercial use, distribution, and reproduction in any medium, provided the original work is properly cited. physical examination. The patient was diagnosed with secondary encopresis (retentive type) and ADHD using the DSMIV-TR criteria. ${ }^{6}$ Behavioral modifications for encopresis were planned, and $27 \mathrm{mg} / \mathrm{d}$ of long-acting methylphenidate (LA$\mathrm{MPH}$ ) was initiated for the patient's ADHD symptoms. However, during the next visit, which occurred before the behavioral modifications were initiated, the encopresis, ADHD, and accompanying behavioral problems had disappeared, but the patient experienced irritability and loss of appetite with the LA-MPH medication. After eight months, due to irritability and appetite problems, $25 \mathrm{mg} / \mathrm{d}$ of atomoxetine (ATX) was added to the patient's medication. Two months later, all the patient's ADHD, oppositional behavior, and encopresis symptoms had disappeared, which prompted the clinic to stop the patient's LA-MPH. After the termination of the LA-MPH, encopresis occurred every day for a week, but the ADHD and oppositional behaviors did not. The child's mother restarted the LA-MPH, and the encopresis disappeared again.

\section{DISCUSSION}

ATX and MPH have been reported to be effective in treatment of encopresis concomitant with ADHD. ${ }^{2-5,7}$ Some authors suggest that the anti-encopretic effects of MPH or ATX may be related to the direct impact they have on executive functioning, self-organizing skills, and impulse control, which enable children to recognize and respond to internal cues to defecate; ${ }^{2}$ however, the positive effects on ADHD may be secondary to the resolution of child-parent relationship conflicts 
and poor social and school functioning. ${ }^{3}$

In the present case, despite the attention problems of the patient recovered with ATX, the encopretic symptoms did not change with this medication. In another retrospective study in which patients were treated with $\mathrm{MPH}$, no association between improvements in attention, hyperactivity, or behavioral problems and improvement in the encopretic symptoms ${ }^{8}$ occurred. In another case, a non-ADHD encopretic patient's encopretic symptoms disappeared with LA-MPH. ${ }^{4}$ Therefore, $\mathrm{MPH}$ may have an effect on encopretic symptoms independent of ADHD symptoms. This case supports that assumption. Also, a statistically significant association between ADHD and an increased risk of encopresis could not have been demonstrated in a recent study. ${ }^{9}$

The researchers have found no study that investigates the peripheral effects of MPH on the gastrointestinal system (GIS). Amphetamine, which has similar effects as MPH, was found to reduce the gastric emptying and intestinal motility via the D1 and D2 receptors in rats. ${ }^{10}$ Dopamine is effective in GIS motility, and the GIS contains the D1 and D2 receptors. ${ }^{11}$ Moreover, the GIS contains dopamine transporter which is inhibited by MPH, and dopamine levels increase due to this inhibition. ${ }^{12}$ However, norepinephrine in the GIS does not originate from intrinsic enteric neurons; it originates from the enteric projections of extrinsic (sympathetic) neurons. ${ }^{11}$ This knowledge may help to explain why the encopretic symptoms recovered with MPH instead of ATX.

The anti-encopretic effects of MPH may be related to its direct peripheral effects on GIS motility rather than its effects on executive functioning, self-organizing skills, or impulse control. Future studies investigating the peripheral effects of MPH on the GIS will improve the knowledge of this topic.

\section{REFERENCES}

1. Johnston BD, Wright JA. Attentional dysfunction in children with encopresis. J Dev Behav Pediatr 1993;14:381-385.

2. Golubchik P, Weizman A. Attention-deficit hyperactivity disorder, methylphenidate, and primary encopresis. Psychosomatics 2009;50:178.

3. Bilgiç A. The possible effect of methylphenidate on secondary encopresis in children with attention-deficit/hyperactivity disorder. Progr Neuropsychopharmacol Biol Psychiatry 2011;35:647.

4. Yilmaz S. Akça ÖF. Effectiveness of methylphenidate in the treatment of encopresis whether or not attention-deficit/hyperactivity disorder symptoms are present. J Child Adolesc Psychopharmacol 2013;23:632-633.

5. Akça ÖF. Disappearence of encopretic symptoms in treatment of attention deficit hyperactivity disorder with methylphenidate extended release medication: two case reports. Klinik Psikiyatri 2011;14:115-118.

6. American Psychiatric Association. Diagnostic and Statistical Manual of Mental Disorders, 4th Edition Text Review (DSM-IV-TR). Washington, DC: American Psychiatric Association; 2000.

7. Hergüner S, Hergüer A. Atomoxetine for encopresis in 2 children with attention-deficit/hyperactivity disorder. J Clin Psychopharmacol 2012; 32:302-303.

8. Yllmaz S, Bilgiç A, Hergüner S. Effect of OROS methylphenidate on encopresis in children with attention-deficit/hyperactivity disorder. Eur J Child Adolesc Psychopharmacol 2014;24:158-160.

9. Mellon MW, Natchev BE, Katusic SK, Colligan RC, Weaver AL, Voigt $\mathrm{RG}$, et al. Incidence of enuresis and encopresis among children with attention-deficit/hyperactivity disorder in a population-based birth cohort. Acad Pediatr 2013;13:322-327.

10. Huang WJ, Chien EJ. The roles of dopamine receptor and adrenoreceptor on the inhibition of gastric emptying and intestinal transit by amphetamine in male rats. Chin J Physiol 2012;55: 259-266.

11. Li ZS, Schmauss C, Cuenca A, Ratcliffe E, Gershon MD. Physiological modulation of intestinal motility by enteric dopaminergic neurons and the D2 receptor: analysis of dopamine receptor expression, location, development, and function in wild- type and knock-out mice. J Neurosci 2006;26:2798-2807.

12. Li ZS, Pham TD, Tamir H, Chen JJ, Gershon MD. Enteric dopaminergic neurons: definition, developmental lineage, and effects of extrinsic denervation. J Neurosci 2004;24:1330-1339. 